\title{
Political Culture of the Arab Community in Germany - A Field Study
}

\author{
Hasan Abdullah Al-Dajah ${ }^{1}$ \\ ${ }^{1}$ Department of Human Security, College of Strategic Studies, Naif Arab University for Security Sciences, Saudi \\ Arabia \\ Correspondence: Hasan Abdullah Al-Dajah, Head of Department of Human Security, College of Strategic \\ Science, Naif Arab University for Security Sciences, Saudi Arabia. E-mail: hasanayed@nauss.edu.sa
}

Received: August 17, $2015 \quad$ Accepted: October 21, $2015 \quad$ Online Published: November 29, 2015
doi:10.5539/jpl.v8n4p191

\begin{abstract}
The objective of this research to know the views members of the Arab community hold towards the political culture in its three dimensions. Members of the Arab community in Germany (ACG) were asked as well as about the sources of political information and about their views about the current events in the Arab world (Arab Spring). After reviewing relevant literature and concepts of political culture the researcher developed a questionnaire which was distributed to members of the ACG in several German cities of different sizes, both in West and East Germany.
\end{abstract}

The study used package (SPSS) statistical analysis of the study and adoption of percentages and frequencies, averages and standard deviations to examine the study questions and used Independent Samples Test to examine the hypotheses of the study. The results of the study indicate that the political culture of the Arab community in Germany is close and homogeneous and that the similarity of the political and social environment outweighs the differences of the many Arabian countries of origin. The reason for this is attributed to the fact that Germany as the hosting country is governed by the principles of democracy and political and cultural pluralism, , and this in turn reflects positively on the political culture of the members of the Arab community which is integrated rather than fragmented.

On a political level the study has shown that communication between the formal and informal German institutions with members of the Arab community needs to be improved and that members of the Arab community in Germany need to be encouraged to get involved and participate more in political life in Germany regarding both, general elections and affiliation to German political parties.

Keywords: political culture, Arab community, Germany

\section{Introduction}

There are many theoretical definitions of the concept of political culture, but most experts agree in the field of comparative politics that "the concept of political culture can be seen as a natural evolution in the growth of the behavioral approach in political analysis, for it represents an attempt to apply to problems of aggregate or systemic analysis the kinds of insights and knowledge which were developed initially by studying the political behavior of individuals and small groups".

There is also a close relationship between political culture and democracy. It is necessary to study the importance of these cultural values as an analysis describes the relations prevailing in the society on the one hand and the interrelationships between the political and social systems on the other.

Political culture differs from one community to another because of its close association with a set of political, religious, social, and economic criteria and factors as well as the historical circumstances of each community. It also changes according to some circumstances, cultural contexts and values, and the large shifts in the system of governance, economic and social policies.

The Government, in its various forms, is interested in political culture because of their important effects on various aspects of political life, especially those related to issues of political support for the system and the political legitimacy and political participation.

Democracy is not just the laws and political institutions and electoral processes and procedures to manage the institutional relationship between the state and society, but it is a set of values and principles that serve as the 
cultural context of a democratic system.

In addition, there is a system of negative values prevailing in some societies to obey authority with suspicion. We can say that the democratic values of democratic political culture are not specific to the formulation of patterns of relationships and interactions within the institutions of the Arab communities (family, school, university, association, union, union). These institutions have contributed in various ways to re-produce values in the form of authoritarian forms of political culture for these communities.

This study intersects with some other studies on political culture. It investigates the views of individuals towards themselves and towards others and towards the structure of government and its policies in Germany.

\subsection{The Framework \& Concept(s) of Political Culture}

In 1983, thirty years after the first publication the classic study "The Civic culture" by Gabriel Almond and Sidney Verba which had established political culture as a concept for empirical research the German political scientist Max Kaase criticised the concept as being so vague and diffuse that researchers in political science and neighboring disciplines could not be understood to mean the same thing by the same words. He compared the attempt to precisely define the concept of political culture to "trying to nail jelly to a wall" (Kaase 1983). In the twenty years since Kaase's consequential article it has become more and more clear that there are basically two different concepts of political culture, one that is going back to the empirical, comparative perspective of Almond and Verba and another that is rooted in cultural studies and employs an interpretative methodology.

For Almond and Verba "the term political culture.. refers to specifically political orientations - views toward the political system and its various parts, and views toward the role of the self in the system. We speak of a political culture just as we can speak of an economic culture or a religious culture. It is a set of orientations toward a special set of social objects and processes." (Almond/Verba: 1963, 13) These orientations could be surveyed through representative samples on the individual level and the aggregated data were used to describe and to compare the political culture of the five nations of the Civic Culture-study. Almond and Verba specified the "special set of social objects" as the political system as a whole, the self as a political role, the system input, and the views toward the system output; each of these orientations has a cognitive, an affective and an evaluation dimension (ibid., 15-20). Under the impression on the one hand of the failure of many democracies in the inter-war years and, on the other hand, of the need to stabilize many new, decolonized states the underlying purpose of the study was to provide an additional variable - complementary to structures and institutions - to explain the stability or instability of political systems. Congruence between the type of the political system and the type of political culture - Almond and Verba constructed three ideal types: the parochial, the subject, and the participant culture roughly corresponding to pre-modern states, to autocracies and to democracies - would be considered as an indicator for stability.

Although Almond and Verba's concept was criticized in many respects (for instance because of its normative Anglo-American bias and its alleged conservatism [Westle: 2009, 26-9]) its great merit has been nonetheless that it served as starting point for many empirical studies either of the political culture of nations or of sub-national unities (Edinger/Hallermann 2004), of subcultures within societies or of specific aspects of political culture such as political trust (Zmerli/Hooghe 2011) or values (Inglehart/Welzel 2010). As a consequence, today we have a great wealth of data resources on political culture at our disposal which has been accumulated by regular surveys (as e.g. the Eurobarometer) or by empirical research, mostly in the Western world but also increasingly in other countries, which allow for comparative studies over time (Conradt 1989).

Empirical research of political culture in the Almond-Verba-tradition is employed also in migration studies where the views and orientations of first or second generation immigrants are concerned (Wilamowitz-Moellendorff: 2001). It can also be useful to compare the political cultures of country of origin and the country of residence of distinct in order to assess how much the political context changes for immigrants. This is also the approach used in this study.

Since the 1970s and 1980s the "cultural turn" gained ground in the social sciences; the cultural studies and the rise of constructivism had a distinct influence on the study of political culture (Street 1994: 104). In Germany, Karl Rohe was an influential scholar who shifted the emphasis in the study of political culture to the specifically cultural aspects. In his view the most important aspects of political culture are not the individual views and orientations that are in the focus of the empirical survey research but rather the underlying assumptions about the political world that are collectively shared by a social group, either a nation or smaller entities. Rohe used several metaphors such as the 'political code' or 'programming' of a society to illustrate what he meant by these underlying assumptions or worldviews. Political culture is thus understood as a framework of meaning that is normally to such an extent self-evident to people that they do not reflect upon it. Surveys, so claimed Rohe, 
cannot reach this deeper layer of political culture which is more or less subconscious and can only be studied through collective expressions of political culture such as symbols or language (Rohe 1990: 331). Even though political culture is shaped by historical experiences of social groups that does not mean in Rohe's view that it is unalterable. Rather, political culture is seen as process of renewal or dismissal for instance of symbols (Dörner: 1996). Symbols and the meaning they transport are (or can be) objects of competition of different elites who offer their competing constructions of meaning to the social group as a whole (Rohe 1994: 168-170); a case in point are the fierce debates and struggles of German intellectuals and historians over the interpretation of the Nazi past (Kailitz: 2001; Bergen 2000). Thus, with this elite competition an almost Gramscian perspective of power comes back to the concept of political culture that had been more or less absent in the empirical Almond and Verba tradition.

Obviously, this strand of political culture research is more diverse and pluralistic than the classic survey research. From narrative interviews to ethnological methods in the Clifford Geertz tradition, from linguistic and semantic methods to all kinds of textual analysis, the interpretative tools are determined by the specific research interest. For migration studies many of these methods can be useful depending what aspect of political culture is to be studied; specific expectations, identities, the political meaning of religion, and experiences of acculturation might better be researched by narrative interviews than in surveys (e.g. Gianni et. al. 2005). Some of these methods might be employed in further research to better understand some of the findings of this study.

\subsection{Importance of the Research}

The importance of the study of political culture of the Arab community in Germany is of two types: scientific importance because this study is the first of its kind to the best of our knowledge.

practical importance; the study will provide significant contributions for researchers and political decision makers.

\subsection{Problem of the Study in the Form of Questions as Follows}

The study will provide answers for the following questions:

What are the views of the Arab community about their own roles in the German society (receiving country)?

What are the views of the Arab community toward other communities in the German society (receiving country)?

What are the views of the Arab community on the structure of the German government and its policies?

What are the views of Arab community in Germany with regard to the political reforms in Arabian countries (Arab spring of 2011/12)?

\subsection{Hypotheses of the Study}

The first hypotheses:

Null hypothesis: There were no statistically significant differences on the views of members of the Arab community in Germany affecting various views of political culture, and political culture as a whole, due to the fact that they are residing in West or East Germany.

Alternative hypothesis: There were statistically significant differences on the views of members of the Arab community in Germany affecting various views of political culture, and political culture as a whole, due to the fact that they are residing in West or East Germany.

Explanation: Given the fact that East Germany has the reputation of being more xenophobic (larger share of right-wing votes, incidents of xenophobic violence) than West Germany which has a much longer tradition of integrating foreign migration, this might have an impact on the way the Arab community perceives its own role within the political society and how it regards German society and government.

The second hypotheses:

Null hypothesis: There were no statistically significant differences on the views of members of the Arab community in Germany affecting various views of political culture, and political culture as a whole, due to the fact that they live in big or small cities.

Alternative hypothesis: There were statistically significant differences on the views of members of the Arab community in Germany affect various views of political culture, and political culture as a whole, due to the fact that they live in big or small cities.

Explanation: In small cities they Arab community is likely to be much smaller as well. Thus the incentives for 
members of the Arab community to learn the German language and to integrate into German society in order to manage everyday lives may be much greater than in big cities with much larger Arab communities where it would be more easy to remain within the bounds of the own ethnic community.

\section{Literature Review}

- Gharaibeh 1994 study was aimed to know the pattern of the prevailing political culture among the students of the University of Yarmulke- Jordan, and the effect of some variables such as sex, religion and income.. Etc. The Rosenbaum model was used and has concluded that the pattern of political culture in general is an integrated pattern.

Ayed. Mubark. \& AL-Oweimer(2011),Attitudes of the Arab Community in Relation to Cultural Identity and Social Integration in Germany

This study firstly aims to investigate the relationship between cultural identity and social integration. Also the results showed that there was a positive significant relationship between cultural identity and social integration. The results also showed that there were no significant differences in all independent variables according to cultural identity. In relation to social integration, the differences were significant regarding income, getting German nationality and getting back the original nationality after obtaining a German passport. The significant scores (?) were favoring for high income, getting German nationality and favoring for those did not get back their original nationality.

Al-Dajah, Oppelland, Mubark, AL-Oweimer, Malkawi (2014),Political Integration Levels of Arab Community in Germany,

This study aimed to examine the Political Integration Levels between persons who got German nationality and persons who did not get German nationality. The results showed that there are significant differences according to education and spouse nationality for Arabs who got German nationality, favoring high education and German wife nationality. In contrast, there were no statistical significances on the other variables in either getting the nationality or not getting.

Gharaibeh and Nofal (2004) studied the political culture of the Jordanian school students, and they found that there is a weakness among secondary school students in Jordanian schools in three aspects of political culture: knowledge, effectiveness and political trust.

Omari (1998) studied the impact of socio-economic variables on the pattern of the political culture of Jordanian university professors and he came to the conclusion that the pattern of the political culture of the Jordanian university professors are integrated pattern on the one hand and fragmented pattern of the other hand.

Qoran (2005) examined the pattern of political culture in the Jordanian countryside represented in rural area of north Jordan, and concluded that the pattern of political culture among members of the sample fragmented where the mean of the percentage degree of approval on all study equal to 34.270 , which is less than $50 \%$ above the limit required to consider that an integrated pattern of political culture in addition to the citizens of the sample views toward others and toward self and toward the political system in general moving towards negative or less than $50 \%$.

The study of the Atweel and Qoran (2009) aimed to identify the impact of a course of (civil-education) national education in bringing about change in the pattern of political culture among the students of the University of Al-Hussein Bin Talal. They reached the conclusion that there are effects of the teaching of national education courses to change the views of students towards their self and to change their views towards others while there is no impact of the national education course in changing students' views toward the government structure.

But with all the comparisons and previous studies, there are very few studies dealing with the subject of the political culture of the Arab community in Germany,

Instrument of the study

The researcher prepared a questionnaire to identify the subject of the study factors and variables, effects on the political culture variables such as age, gender, education income, period of stay in Germany, place of current residence, restoration of the original nationality after obtaining German nationality.

\section{Research Methodology}

Methodology: the study used package (SPSS) statistical analysis of the study and adoption of percentages and frequencies, averages and standard deviations to examine the study questions and use Independent Samples Test to examine the hypothesis of the study. 
The study sample consists of members of the Arab community living in Germany and was selected randomly.

Depending on the model developed by American scientist Rosenbaum in 1975, political culture is divided into three components:

First: the views of individuals and their political views about their role in society, so that this element is measured based on:

i) Political efficiency (Political Competence): which are the desires of individuals and their feelings about participation through public activities and the exercise of political life?

ii) Political activism (Political Efficacy): individuals' feeling that their participation in political life is effective.

Second: views of individuals and their political views to others in the society; this will be measured by:

Political identity: the feeling of belonging.

Political trust: the willingness of the individuals to cooperate with each other's.

Third: views of individuals and their political views on the government structure; this is measured by:

i) Views of individuals and their political views about the formal political institutions.

ii) Views of individuals and their opinions on policies issued by the government.

The study population: In 2010 the German statitics department counted 272, 569 Arabs living in Germany.(2010 G. statistics) and in 2011 the number of Arabs living in Germany had grown to 286, 649 (2011 German statistics)

The study population was 286, 649 (Note 1), and the sample taken from different regions of the Germany; the target group was 57232 and the sample was 530 i.e. roughly $1 \%$ of the target group. The questionnaires were distributed in different geographical areas as described in the hypotheses; distribution could not correspond to the exact distribution of the Arab community in Germany but was limited by financial and time resources of the researcher; yet all criteria (East and West Germany, big and small cities) were met. Table 1 shows the distribution of the returned questionnaires.

Table 1. The target group according the respondent cities

\begin{tabular}{llll}
\hline Cities & Repetition & Percentage $\%$ * & Number the Arab community members in the German cities \\
\hline Berlin & 239 & 45.1 & 20823 \\
Jena & 81 & 15.3 & 240 \\
Düsseldorf & 56 & 10.6 & 8153 \\
Erfurt & 44 & 8.3 & 542 \\
Mannheim & 39 & 7.4 & 2052 \\
Frankfurt/M. & 33 & 6.2 & 8532 \\
Gera & 9 & 1.7 & 119 \\
Heidelberg & 9 & 1.7 & 1025 \\
Hannover & 3 & 0.6 & 7607 \\
Aachen & 2 & 0.4 & 4482 \\
Apolda & 2 & 0.4 & 6 \\
Essen & 2 & 0.4 & 6257 \\
Halle & 2 & 0.4 & 1241 \\
Heilbronn & 2 & 0.4 & 418 \\
Weimar & 2 & 0.4 & 141 \\
Munich & 1 & 0.2 & 16409 \\
Others & 4 & 0.8 & 8 \\
\hline Total & 530 & 100 & 57224 \\
\hline
\end{tabular}

*This percentage compared to the number of members of the actual sample (530). 
Instrument of the study:

The researcher - after identifying the problem of the study - prepared a questionnaire to cover the (14) variables such as: residence, age, sex, profession, and qualification of respondents, and , income, marital status, German language scale , German citizenship, husband / wife.. etc. The questionnaire was divided into the following areas:

First: views members of the Arab community about their role in society.

Secondly: the members of the Arab community views toward others in German society.

Thirdly: the members of the Arab community views towards the German government.

Fourth: sources of political information of individuals of the Arab community in Germany.

-1. Sources of political information if the individual was born in the country of origin.

-2. Sources of political information for members of the Arab community born in Germany.

Fifth: views of (ACG ) about the events taking place in the Arab countries during the current period (the Arab Spring).

Stability of the tool:

To ensure the content validity of the study instrument and the persistence of the researcher he sent it for arbitration by a group of specialists consisting of eight members: three from major political science, and five members from different academic disciplines such as sociology, economics and statistics; after some observations and suggestions the questionnaire was adopted unanimously approved by $85 \%$. In additon o this, the author discussed the instrument MA and $\mathrm{PhD}$ students of political science in Friedrich-Schiller-University Jena, Germany. After these procedures, the researcher deleted some unsuitable items, and reworded the misunderstandable items until the last version developed. The instrument has the following domains: Political Culture with 4 fields that is:

First: views members of the Arab community about their role in society (3 items ).

Secondly: the members of ACG views toward others in German society (5 items ).

Thirdly: the members of ACG views towards the German government (4 items ).

Fourth: sources of political information of members of ACG (7 items).

- 1. Sources of political information if the members of ACG were born in the country of origin (4 items).

-2. Sources of political information for members of ACG born in Germany (3 items).

Fifth: views of ACG about the events taking place in the Arab countries during the current period (the Arab Spring) ( 5 items).

To investigate the degree of stability of the tool coefficients (Cronbach's Alpha) for all fields of study have been extracted.

The coefficients listed in table 1 indicate that the study tool enjoys a high degree of stability which justifies its use.

Table 2. Chronbach's Alpha of the study tool items

\begin{tabular}{ll}
\hline Items & Chronbach's Alpha Value \\
\hline Members of the Arab community about their role in German society & 0.815 \\
Members of the Arab community and their views toward others in German society & 0.681 \\
Views in Arab community towards German government & 0.713 \\
Sources of political information for members of the Arab community in Germany & 0.656 \\
About the events taking place in the Arab countries during the current period & 0.656 \\
All items & 0.844 \\
\hline
\end{tabular}

All the study tool items are reliable because of the value of Chronbach's alpha were more than 0.60.

Demographic Characteristics of the sample: 
At the beginning of the review of the results of analysis of the study, we would like to show the demographic characteristics of the study sample as shown in Table below.

Table 3. Distribution of the sample according to demographic characteristics.

\begin{tabular}{|c|c|c|c|}
\hline Characteristic & & Frequency & Percentage \\
\hline \multirow{6}{*}{ Age } & $18-25$ & 91 & 17.3 \\
\hline & $26-33$ & 152 & 29.5 \\
\hline & $34-41$ & 138 & 26.3 \\
\hline & $42-49$ & 76 & 14.5 \\
\hline & 50 and above & 68 & 13.0 \\
\hline & Total & 525 & 100.0 \\
\hline \multirow{3}{*}{ Gender } & Male & 430 & 96.9 \\
\hline & Female & 98 & 2.1 \\
\hline & Total & 528 & 100 \\
\hline \multirow{4}{*}{ Religion } & Islam & 502 & 96.9 \\
\hline & Christianity & 11 & 2.1 \\
\hline & Zide (Note 2) & 5 & 1.0 \\
\hline & Total & 518 & 100.0 \\
\hline \multirow{7}{*}{ Length of stay in years } & $1-5$ & 165 & 32.8 \\
\hline & $6-10$ & 99 & 19.7 \\
\hline & $11-15$ & 81 & 16.1 \\
\hline & $16-20$ & 62 & 12.3 \\
\hline & $21-30$ & 53 & 10.5 \\
\hline & 30 and above & 43 & 8.5 \\
\hline & Total & 503 & 100 \\
\hline \multirow{4}{*}{ German language proficiency } & Good & 246 & 48.3 \\
\hline & Average & 177 & 34.8 \\
\hline & Few & 86 & 16.9 \\
\hline & Total & 509 & 100.0 \\
\hline \multirow{16}{*}{ The country of origin } & Palestine & 92 & 17.4 \\
\hline & Syria & 67 & 12.7 \\
\hline & Jordan & 58 & 11.0 \\
\hline & Egypt & 53 & 10.0 \\
\hline & Morocco & 50 & 9.5 \\
\hline & Lebanon & 49 & 9.3 \\
\hline & Iraq & 41 & 7.8 \\
\hline & Algeria & 39 & 7.4 \\
\hline & Tunisia & 27 & 5.1 \\
\hline & Libya & 20 & 3.8 \\
\hline & Yemen & 16 & 3.0 \\
\hline & KSA & 8 & 1.5 \\
\hline & Oman & 3 & 0.6 \\
\hline & Sudan & 3 & 0.6 \\
\hline & UAE & 2 & 0.4 \\
\hline & Total & 528 & 100.0 \\
\hline
\end{tabular}




\begin{tabular}{|c|c|c|c|}
\hline Characteristic & & Frequency & Percentage \\
\hline \multirow{6}{*}{ Education } & $\begin{array}{l}\text { Less than high } \\
\text { school }\end{array}$ & 85 & 17.3 \\
\hline & High school & 136 & 27.6 \\
\hline & Diploma & 93 & 18.9 \\
\hline & Bachelor & 139 & 28.3 \\
\hline & Graduate & 39 & 7.9 \\
\hline & Total & 492 & 100.0 \\
\hline \multirow{11}{*}{ Business } & Private business & 155 & 34.4 \\
\hline & Services sector & 80 & 17.7 \\
\hline & $\begin{array}{l}\text { Governmental } \\
\text { sector }\end{array}$ & 58 & 12.9 \\
\hline & Agricultural works & 4 & .9 \\
\hline & Industrial works & 29 & 6.4 \\
\hline & Unemployed & 52 & 11.5 \\
\hline & Retired & 15 & 3.3 \\
\hline & $\begin{array}{l}\text { Exempt from work } \\
\text { for health reasons }\end{array}$ & 10 & 2.2 \\
\hline & $\begin{array}{l}\text { Work in private } \\
\text { companies }\end{array}$ & 30 & 6.7 \\
\hline & $\begin{array}{l}\text { Prohibited from } \\
\text { working }\end{array}$ & 18 & 4 \\
\hline & Total & 451 & 100 \\
\hline
\end{tabular}

As shown in table 3, male Arabs are somewhat overrepresented in the sample (96.9\%), whereas the highest rate of Arabian females is in the age group between 26-33 years and 34-41 years, 29.5\% and 26.5\% respectively. That the overwhelming majority of the sample $(96.6 \%)$ is of the religion of Islam, compared to $2.1 \%$ Christians and $1.0 \%$ of the Yezidi religion roughly corresponds to the religious structure in most Arab countries of origin (with the notable exception of the Lebanon). while the Category residence of $1-5$ years as $32.8 \%$ while the percentage of those who speak the German language at a good level of $48.3 \%$ and were these Arabs are from Palestine percentage $17.4 \%$ while reached the highest rate in education to those who are in high school and percentage for $27.6 \%$.

$34.4 \%$ of the ACG in the sample are employed in private business. Two more figures are noticeable: $47.2 \%$ of the ACG in the sample earn less than 1000 Euros per month and would be considered more or less "poor" by German standards; only $6.5 \%$ of the participants in the study was born in Germany and only a third has obtained the German nationality.

Table 4. Sample distribution by monthly income

\begin{tabular}{lll}
\hline Monthly income & Frequency & Percentage \\
\hline Less than 1000 & 230 & 47.2 \\
$1001-2000$ & 180 & 37.0 \\
$2001-3000$ & 49 & 10.1 \\
$3001-4000$ & 18 & 3.7 \\
$4001-5000$ & 4 & 0.8 \\
5000 and above & 6 & 1.2 \\
Total & 487 & 100 \\
\hline
\end{tabular}


Table 5. Distribution of the sample by birth in Germany

\begin{tabular}{lll}
\hline Birth in Germany & frequency & Percentage \\
\hline Yes & 34 & 6.5 \\
No & 491 & 93.5 \\
Total & 525 & 100 \\
\hline
\end{tabular}

Table 6. Distribution of sample by obtaining German nationality

\begin{tabular}{lll}
\hline Obtaining German nationality & frequency & Percentage \\
\hline Yes & 173 & 33.1 \\
No & 352 & 66.9 \\
Total & 525 & 100 \\
\hline
\end{tabular}

Table 7. Sample distribution by nationality of the husband / wife

\begin{tabular}{lll}
\hline Nationality of husband/wife & frequency & Percentage \\
\hline German & 121 & 26.4 \\
European & 61 & 13.3 \\
Arabian & 207 & 45.3 \\
Single & 69 & 15.1 \\
Total & 458 & 100 \\
\hline
\end{tabular}

Table 8 . sample distribution by the purpose of residence in Germany

\begin{tabular}{lll}
\hline The purpose of residence in Germany & frequency & Percentage \\
\hline Studying & 137 & 26.6 \\
Working & 130 & 25.2 \\
permanent residence & 173 & 33.6 \\
Temporary residence & 41 & 8.0 \\
Marriage & 34 & 6.6 \\
Total & 515 & 100 \\
\hline
\end{tabular}

\section{The Results of the Study}

This study aimed to identify the impact of variables to the political culture of the Arab community, and to achieve this goal means and standard deviations for paragraphs study and areas have been extracted taking into account that the three degrees used in this study; therefore items and areas ranging means (3.68 - 5) have a high impact on political culture, items and areas that range averages between $(2.34$ - 3.67) have an medium impact on political culture, while the paragraphs that range between $(1-2.33)$ indicate a low degree of impact on political culture. also has been converted mean ratio Celsius over the following calculation method; Namely: Mean $\times 20$ $=\%$.

According to the Rosenbaum model which was applied in this study any outcome of $50 \%$ and above that would suggest an integrated pattern of political culture and any outcome of $49.9 \%$ or less would suggest a fragmented political culture.

\subsection{Result \& Dissociation}

Answering questions of the study:

In order to answer the questions of the study and discussion; we begin to answer the first question: 
Table 9. Means and Standard deviations for members of the Arab community views about their role in German society in descending order

\begin{tabular}{llllll}
\hline $\begin{array}{l}\text { Items } \\
\text { number }\end{array}$ & Trend's paragraphs & Mean & $\begin{array}{l}\text { Standard } \\
\text { deviation }\end{array}$ & $\begin{array}{l}\text { Member } \\
\text { orientation }\end{array}$ & Rank \\
\hline 1 & $\begin{array}{l}\text { I exercise my right to vote in German parliamentary } \\
\text { elections }\end{array}$ & 3.11 & 1.60 & Medium & 1 \\
& $\begin{array}{l}\text { My participation in political events has effects on the } \\
\text { decisions of the German government and its policies }\end{array}$ & 2.84 & 1.29 & Medium & 2 \\
& $\begin{array}{l}\text { Joining the German political parties affects the } \\
\text { German politics }\end{array}$ & 2.74 & 1.34 & Medium & 3 \\
\hline & 3.08 & 1.21 & Medium \\
\hline
\end{tabular}

As the table above indicates, the total score to level the views of the sample towards the political culture with respect to members of the Arab community views about their role in German society reached (3.08) with a standard deviation (1.21); the political culture range to a moderate degree, has got three paragraphs medium grades as shown in the above table, These results agree with the study of (AL-Dajah \& others: 2013), where the mean average of the political integration is (2.23) for those who have German citizenship, the and the mean average of the overall political participation is in this study (3.08). And transfer to the proportion of Mean average, and becomes as a result of the total score for the level of the views of the sample towards the political culture with respect to members of the Arab community views about their role in German society, is $61.6 \%$, and compared with the study of (Qura'an 2005), it did not agree with it ,the percentage respondents views toward political culture with regard to members of the Arab community views about their role in society $24.76 \%$. Another study (Atweel and Qura'an 2009) has agreed with our study where the percentage of approval on the orientations of the sample towards the political culture regarding views members of the Arab community about their role in society, and mean average of their study to 3.12 and this agrees with the current study. It also agrees with the study (Gharaibeh 1994) in this area amounted to percentage $50.17 \%$, and the meaning of the comparisons to approximate the view that the political culture of the Arab community converged with the results of studies conducted for the Arabs in their country of origin. the answer the first question: the political culture of the members of the Arab community in Germany is a political culture integrated as mean average (3.08).

The answer of the second question:

2. What are the political views of Arab community toward other communities in the German society (receiving country)?

Table 10. Means and standard deviations for the member's views of the Arab community and their views toward others in German society in descending order

\begin{tabular}{|c|c|c|c|c|c|}
\hline $\begin{array}{l}\text { Items } \\
\text { number }\end{array}$ & Trend's paragraphs & mean & $\begin{array}{l}\text { Standard } \\
\text { deviation }\end{array}$ & $\begin{array}{l}\text { Member } \\
\text { orientation }\end{array}$ & Rank \\
\hline 2 & Germans are democratic in dialogue with others & 3.53 & 1.12 & Medium & 1 \\
\hline 3 & $\begin{array}{l}\text { The German community is influencing the course } \\
\text { of political issues }\end{array}$ & 3.50 & 1.15 & Medium & 2 \\
\hline 1 & $\begin{array}{l}\text { I discuss political issues with members of } \\
\text { German society }\end{array}$ & 3.45 & 1.32 & Medium & 3 \\
\hline 5 & $\begin{array}{l}\text { I think that the German community is tolerant } \\
\text { toward the Arab community }\end{array}$ & 3.06 & 1.09 & Medium & 4 \\
\hline 4 & $\begin{array}{l}\text { Germans care about political issues of the Arab } \\
\text { community }\end{array}$ & 2.91 & 1.09 & Medium & 5 \\
\hline \multicolumn{2}{|c|}{ Total degree } & 3.29 & 1.15 & & \\
\hline
\end{tabular}


As shown in Table above the total score for the level of political culture of the Arab community in Germany has reached (3.29) with a standard deviation (1.15), suggesting that the political culture of the Arab community regarding views of members of the Arab community towards others in German society medium.

The transformation of the result to the Celsius equivalent ratio mean an average of $60.8 \%$ and this is an integrated political culture. This result agrees with the study of (Gharaibeh 1994) with respect to the members of the Arab community views towards others in the community which stood at $62.6 \%$ and it agreed with the study (Atweel and Qura'an 2009) as the mean average for this totaled $44.98 \%$, while it disagreed with the study of (Qura'an 2005), where the rate was parentage $44.43 \%$.

And as the answer to this question, it turns out that the pattern of political culture of members of the Arab community is an integrated political culture, meaning that members of the Arab community views in Germany very close.

The third question:

The answer to the third question: what views do members of the Arab community in Germany hold towards the German government? Shown on table below:

Table 11. Means and standard deviations for member's views in the Arab community towards the German government in descending order

\begin{tabular}{llllll}
\hline $\begin{array}{l}\text { Items } \\
\text { number }\end{array}$ & Trend's paragraphs & mean $\begin{array}{l}\text { Standard } \\
\text { deviation }\end{array}$ & $\begin{array}{l}\text { Member } \\
\text { orientation }\end{array}$ & Rank \\
\hline 1 & $\begin{array}{l}\text { The services offered by the German government } \\
\text { meet the requirements for a decent life for people }\end{array}$ & 4.05 & 0.91 & High & 1 \\
& $\begin{array}{l}\text { Official German politicians enjoy political } \\
\text { efficiency }\end{array}$ & 3.56 & 1.35 & Medium & 2 \\
& $\begin{array}{l}\text { I trust the current composition of the German } \\
\text { government }\end{array}$ & 2.95 & 1.19 & Medium & 3 \\
2 & I trust German politicians & 2.94 & 1.20 & Medium & 4 \\
Total degree & 3.38 & 1.16 & Medium & \\
\hline
\end{tabular}

As indicated above the total score for the level views of the sample towards of members of the Arab community toward the German government reached (3.38) with a standard deviation (1.16), suggesting that the political culture of the Arab community were among the mean average. has got paragraphs $(2,3.4)$, medium grades, while won the first paragraph on the mean high average. converts the mean to Celsius rate becomes $67.6 \%$, and this role makes this study different from the study of (Gharaibeh 1994) as the percentage reached when Gharaibeh views sample toward the government were $25.9 \%$, also differed from study (Qura'an 2005), amounting to $26.61 \%$, and also disagreed with the study (Atweel and Qura'an 2009), amounting to $49.9 \%$, while this study was the political culture of the integrated unlike other studies

In order to answer this question, the mean average of the total score reached (3.38) and this is an integrated political culture.

The answering the fourth question:

The answer to the fourth question: What are the sources of political knowledge of members of the Arab community in Germany? 
Table 12. Means and standard deviations for the sources of political information for members of the Arab community in Germany. (those who were born in country of origin to answer the paragraphs $(1,2,3 \& 7)$ those who were born in Germany to answer the paragraphs $(4,5 \& 6))$

\begin{tabular}{|c|c|c|c|c|c|c|}
\hline $\begin{array}{l}\text { Items } \\
\text { number }\end{array}$ & Trend's paragraphs & mean & $\begin{array}{l}\text { Standard } \\
\text { deviation }\end{array}$ & \multicolumn{2}{|c|}{$\begin{array}{l}\text { Member } \\
\text { orientation }\end{array}$} & Rank \\
\hline 7 & $\begin{array}{l}\text { Staying in my country of origin and practical } \\
\text { experiences obtained in Germany }\end{array}$ & 3.76 & 1.10 & \multicolumn{2}{|c|}{ High } & 1 \\
\hline 1 & Family in my country of origin & 3.66 & 1.34 & \multicolumn{2}{|c|}{ Medium } & 3 \\
\hline 3 & Arab media & 3.57 & 1.26 & \multicolumn{2}{|c|}{ Medium } & 4 \\
\hline 2 & $\begin{array}{l}\text { Educational and academic institutions in my } \\
\text { country of origin }\end{array}$ & 3.35 & 1.29 & \multicolumn{2}{|c|}{ Medium } & 7 \\
\hline 5 & \multicolumn{2}{|l|}{ Educational and academic institutions in Germany } & 3.68 & 1.11 & High & 2 \\
\hline 4 & \multicolumn{2}{|l|}{ Family and the Arab community in Germany } & 3.44 & 1.08 & Medium & 5 \\
\hline 6 & \multicolumn{2}{|l|}{ German media } & 3.38 & 1.26 & Medium & 6 \\
\hline \multicolumn{3}{|c|}{ Total degree } & 3.55 & 1.20 & Medium & \\
\hline
\end{tabular}

As the table above indicates the total score for the level of political culture sources for the Arab community in Germany has reached (3.55) with a standard deviation (1.20), which indicates that the sources of the political culture of the Arab community was medium, has got paragraphs medium grades,

It has got the paragraph that shows the source of the political culture of 'Staying in my country of origin' and practical experiences obtained in Germany got high mean average reaching (3.76) as the subsequent following paragraph; educational and academic institutions in Germany reached high mean average that is (3.68), while the other paragraphs won a medium average. To answer this question it has been shown that members of the Arab community political culture sources are many and varied, as shown by the table above.

The answering the fifth question:

The answer to the fifth question: How do members of the Arab community in Germany look upon what is going on in the Arab countries (Arab spring)?

Table 13. Means and standard deviations of the events taking place in the Arab countries during the current period

\begin{tabular}{llllll}
\hline $\begin{array}{l}\text { Items } \\
\text { number }\end{array}$ & Trend's paragraphs & Mean & $\begin{array}{l}\text { Standard } \\
\text { deviation }\end{array}$ & $\begin{array}{l}\text { Member } \\
\text { orientation }\end{array}$ & Rank \\
\hline 3 & $\begin{array}{l}\text { I support the political systems after the } \\
\text { revolutions will provide public security }\end{array}$ & 3.92 & 1.36 & High & 1 \\
& $\begin{array}{l}\text { Arab revolutions will lead to a real democratic } \\
\text { change }\end{array}$ & 3.58 & 1.40 & Medium & 2 \\
& $\begin{array}{l}\text { Arab political systems after the revolutions will } \\
\text { provide public security }\end{array}$ & 3.35 & 1.33 & Medium & 3 \\
& $\begin{array}{l}\text { I participate in activities leading the German } \\
\text { government to support the Arab revolutions }\end{array}$ & 3.13 & 1.48 & Medium & 4 \\
& $\begin{array}{l}\text { I favor the survival of Arab political systems as } \\
\text { they are without change }\end{array}$ & 1.67 & 1.12 & Low & 5 \\
\hline
\end{tabular}

As shown in Table above to the total score for the level views of political culture of the Arab community in 
Germany regarding their view to what is going in the Arab world (Arab Spring) has reached (3.13) with a standard deviation (1.33), which indicates that there is almost a consensus on the views of political culture Arab community regarding tumor being in the Arab world and the medium average, the paragraph that reads;

I support the political systems after the revolutions will provide a public security and won the high mean average (3.92) while the paragraph that reads 'I favor the survival of Arab political systems as they are without change' won the lowest mean average, and this is consistent with the above answer to the preceding paragraph, the remaining paragraphs medium average as shown in the above table.

And the answer to this question is that there is a significant impact of the views of members of the Arab community in Germany about what is happening in the Arab world and this is oriented integrated because of signed mean average over the rate $50 \%$, and the transformation of the mean average on a percentage found amounted to $62.6 \%$ In other words, there is almost an agreement within the sample about what is happening in the Arab countries.

\subsection{Test the Hypotheses of the Study}

To study this phenomenon in depth the hypotheses must be tested on the following key variables; residence in areas of West Germany and in the eastern regions of Germany, and living in the big cities and living in small cities.

First hypotheses Null hypothesis: There were no statistically significant differences on the views of members of the Arab community in Germany affect various views of political culture, and political culture as a whole, due to the difference in place in the areas of housing in West Germany Provinces or the East Germany Provinces.

To test this hypothesis test was conducted (Independent-Sample-T-test), and the results were as follows:

Table 14. Between the mean averages by place of residence in areas or regions of West Germany and East Germany test

Independent Samples Test

\begin{tabular}{|c|c|c|c|c|c|c|c|c|}
\hline Geographic & & $\mathrm{N}$ & Mean & Degree & $\begin{array}{l}\text { Std. } \\
\text { Deviation }\end{array}$ & $\mathrm{t}$-value & Df & Sig \\
\hline $\begin{array}{l}\text { Views members of the Arab } \\
\text { community about their role in } \\
\text { German society }\end{array}$ & $\begin{array}{l}\text { Western } \\
\text { Eastern }\end{array}$ & $\begin{array}{l}145 \\
366\end{array}$ & $\begin{array}{l}3.2069 \\
3.0319\end{array}$ & $\begin{array}{l}\text { moderate } \\
\text { moderate }\end{array}$ & $\begin{array}{l}1.2024 \\
1.2256\end{array}$ & 1.463 & 509 & .144 \\
\hline $\begin{array}{l}\text { Views members of the Arab } \\
\text { community and their views toward } \\
\text { others in German society }\end{array}$ & $\begin{array}{l}\text { Western } \\
\text { Eastern }\end{array}$ & 148 & 2.7172 & $\begin{array}{l}\text { moderate } \\
\text { moderate }\end{array}$ & $\begin{array}{l}.7547 \\
.7651\end{array}$ & .095 & 522 & .924 \\
\hline $\begin{array}{l}\text { Views in Arab community towards } \\
\text { German government }\end{array}$ & $\begin{array}{l}\text { Western } \\
\text { Eastern }\end{array}$ & $\begin{array}{l}148 \\
372 \\
\end{array}$ & $\begin{array}{l}2.5372 \\
2.6832 \\
\end{array}$ & $\begin{array}{l}\text { moderate } \\
\text { moderate }\end{array}$ & $\begin{array}{l}7880 \\
.8934 \\
\end{array}$ & 1.738 & 518 & .083 \\
\hline $\begin{array}{l}\text { Sources of political information for } \\
\text { members of the Arab community in } \\
\text { Germany }\end{array}$ & Western & 143 & $\begin{array}{l}2.4034 \\
2.4103\end{array}$ & $\begin{array}{l}\text { moderate } \\
\text { moderate }\end{array}$ & $\begin{array}{l}.8153 \\
.8155\end{array}$ & .085 & 509 & .932 \\
\hline $\begin{array}{l}\text { about the events taking place in the } \\
\text { Arab countries during the current } \\
\text { period }\end{array}$ & Western & 143 & 2.8195 & $\begin{array}{l}\text { moderate } \\
\text { moderate }\end{array}$ & $\begin{array}{l}.92769 \\
.87588\end{array}$ & .834 & 507 & .405 \\
\hline TOTAL & $\begin{array}{l}\text { Western } \\
\text { Eastern }\end{array}$ & $\begin{array}{l}149 \\
377\end{array}$ & $\begin{array}{l}2.7087 \\
2.7304\end{array}$ & $\begin{array}{l}\text { moderate } \\
\text { moderate }\end{array}$ & $\begin{array}{l}.5373 \\
.5195\end{array}$ & .427 & 524 & .669 \\
\hline
\end{tabular}

Looking at the above table and discussing the first hypothesis, we find that there were no statistically significant differences at the level of $(\alpha \leq 0.05)$ and thus accept the null hypothesis and consequentially reject the alternative hypothesis that there are statistically significant differences in the views of members of the Arab community in Germany due to the fact the people are living in East or West Germany. It can be inferred that the common 
cultural background of the Arab community in Germany is of much greater importance in shaping its political culture than the factor of living either in East or West Germany. As shown in Table (3) respondents came from countries which at least conduct parliamentary elections, and there is some space to express opinions. At the same time Germany is a democratic country where people are encouraged to express their opinions and to participate in politics. Rather minor differences how the members of the Arab community in West Germany view their role in German society (3.2069 vs. 3.0319), may be attributed to the longer tradition of democracy in West Germany since the end of the second world war, East Germany was only liberated from the iron fist of the Soviet Union after the collapse of the Berlin Wall on November 9, 1989., and indicates the total to rise mean average of the total for the benefit of regions of East Germany has reached the mean (2.7304) the views of members of the Arab community of views in political culture, and due to the fact that members of the Arab community in the areas of East Germany their political culture belong to the origins not of hosting country, including carrying with them their own political cultural, and life experience, the multiplicity of views, an influential and influenced by the system social and political state of Germany. thus formed political culture views converged see table above.

When Rosenbaum model is applied to the sample and the mean is converted to the proportion of $\%$ it becomes an overall result of $54.60 \%$ giving proof of an integrated, not fragmented political culture.

But in the final analysis, we find that strong convergence in the overall result which $54.60 \%$ is an indication that the place of residence for members of the Arab community, whether in East or West Germany did not play an important role in influencing the political culture.Since that great majority of the sample resides less than 20 years in Germany cultural effects of GDR heritage and Soviet control over East Germany can not affect the Arab community in East Germany. Apparently, the alleged xenophobia in East Germany does not influence the political culture of Arabs living there either.

The second hypothesis: There were statistically significant differences

at the level of $(\alpha \geq 0.05)$ in the views of members of the Arab community in Germany concerning various views of political culture and political culture as a whole due to the differences of living in big or small cities.

To test this hypothesis test was conducted (Independent-Sample-T-test), and the results were as follows:

Table 15. Mean averages of residents of small towns and big cities and test Independent sample T-test

\begin{tabular}{|c|c|c|c|c|c|c|c|c|}
\hline Size of the city & & $\mathrm{N}$ & Mean & Degree & $\begin{array}{l}\text { Std. } \\
\text { Deviation }\end{array}$ & t-value & $\mathrm{df}$ & Sig. \\
\hline \multirow{2}{*}{$\begin{array}{l}\text { Views members of the Arab community } \\
\text { about their role in German society }\end{array}$} & Big & 326 & 2.8952 & Moderate & 1.1512 & \multirow{2}{*}{4.674} & \multirow{2}{*}{509} & \multirow{2}{*}{.000} \\
\hline & Small & 185 & 3.4099 & Moderate & 1.2719 & & & \\
\hline \multirow{2}{*}{$\begin{array}{l}\text { Views members of the Arab community } \\
\text { and their views toward others in } \\
\text { German society }\end{array}$} & Big & 330 & 2.6793 & Moderate & .7462 & \multirow[b]{2}{*}{1.288} & \multirow[b]{2}{*}{522} & \multirow[b]{2}{*}{198} \\
\hline & Small & 194 & 2.7680 & Moderate & .7855 & & & \\
\hline \multirow{2}{*}{$\begin{array}{l}\text { Views in Arab community towards } \\
\text { German government }\end{array}$} & Big & 330 & 2.9604 & Moderate & .8845 & \multirow{2}{*}{1.694} & \multirow{2}{*}{518} & \multirow{2}{*}{.091} \\
\hline & Small & 190 & 2.5570 & Moderate & .8296 & & & \\
\hline \multirow{2}{*}{$\begin{array}{l}\text { Sources of political information for } \\
\text { members of the Arab community in } \\
\text { Germany }\end{array}$} & Big & 323 & 2.3929 & Moderate & .8331 & \multirow[b]{2}{*}{.562} & \multirow[b]{2}{*}{509} & \multirow[b]{2}{*}{.574} \\
\hline & Small & 188 & 2.4349 & Moderate & .7834 & & & \\
\hline \multirow{2}{*}{$\begin{array}{l}\text { about the events taking place in the } \\
\text { Arab countries during the current } \\
\text { period }\end{array}$} & Big & 323 & 2.8763 & Moderate & .90523 & \multirow[b]{2}{*}{.138} & \multirow[b]{2}{*}{507} & \multirow[b]{2}{*}{.891} \\
\hline & Small & 186 & 2.8650 & Moderate & .86650 & & & \\
\hline \multirow{2}{*}{ TOTAL } & Big & 331 & 2.6953 & Moderate & .5099 & \multirow[t]{2}{*}{656} & \multirow[t]{2}{*}{524} & \multirow[t]{2}{*}{.098} \\
\hline & Small & 195 & 2.7735 & Moderate & .5454 & & & \\
\hline
\end{tabular}

Looking at the above table and discuss the first hypothesis, we find that there were no statistically significant differences at the level of $(\alpha \leq 0.05)$ and thus accept the null hypothesis and then reject alternative hypothesis that there are statistically significant differences in the views of members of the Arab community in Germany affect 
the views of different political culture damnations, and political culture as a whole, due to the differences of living in big or small cities.

There is one exception, however, concerning the views of the members of the Arab community about their own role in society. Those members living in small towns display a more positive view of their role in society which can be attributed to the fact that small towns more coherent and closer in the social relations of the population. who have overcome concern in the affairs of their daily lives, leading to a decline and shrinking political activities.

In addition, the breadth of leisure among the population of small towns is more than the population of the cities, which is a powerful incentive for the members of small towns to prevent with their peers for longer periods of time is a discussion of many of the political issues with complex details.

When the Rosenbaum model is applied and the data converted to proportion the overall results are $55.47 \%$ and this indicates that the political culture of the Arab community members is integrated and not fragmented.

\section{Conclusion}

The objective of this research study the political culture of members of the Arab community in its three dimensions. As another dimension the sources of political information - local in the country of residence or rather from country of origin - were added and it ws inquired how the the members of the Arab community saw what was happening in the Arab world (Arab Spring)., After reviewing literature, deciding on a relevant concept of political culture a questionnaire was developed and small and big cities in East and West Germany were selected where the questionnaire was distributed in July (?) 2012. The returned questionaires were analysed with the statistical analysis package SPSS; and mean averages and standard deviations as well as test (T-Test) were used to check if there are significant statistical differences among the members of the Arab community living in East and West Germany.

It was also checked for differences between residents of small and big cities and residents of small towns but it was found that statistically significant differences were negligible.

The research came to answer five key questions:

1 - To answer the first question about the views of members of the Arab community about their role in society in the host country, the total mean 1 averages (3.08) were converted to a percentage score of $61.6 \%$ which means that the political culture of the members of the Arab community in this dimension is an integrated culture according to the Rosenbaum model.

2 - The second question was about the views of the Arab community members about the role of others in host society reached the mean average of $3.29 \%$ and converted to a percentage $65.8 \%$, suggesting also that the political culture of the Arab community members is integrated according to the Rosenbaum model.

3 - On the third question the views of members of the Arab community toward the government and its companion the mean average of the total was $3.38 \%$ and converted to a percentage $67.6 \%$ and this again, of course, indicates that the culture of political members of the Arab community is integrated according to the Rosenbaum model.

4 - As for the sources of political culture was the most important sources of political culture are:

Residence in the country of origin and practical experience acquired by an individual in Germany. The high level as the mean average $(3.76 \%)$ and equals $75.2 \%$. This was followed by source of educational and academic institutions in Germany and the mean average of $3.68 \%$, equals $73.6 \%$. this means that to stay in Germany a major role in providing members of the Arab community information sources.

5 - The fifth question was about the Arab community views about what is happening in the Arab world (Arab Spring). The highest average account is to support the post-revolution political systems if they are able to provide public security to the people; the mean average was 3.92. And the lowest average account is in favor of the survival of Arab political systems as they are without change; the mean average was (1.67) equaling (33.4\%) which indicates a lack of satisfaction of the Arab community members with the (formerly) ruling political regimes.

\subsection{Results of Hypotheses}

As for the research hypotheses and the level of political culture to residents of small towns and residents of big cities and the people of Arab community living in East Germany and West Germany,, the results were negative, there was no statistical significance between the residents of these areas and political culture. 
Finally: The results of the study indicate that the political culture of the Arab community is very close and homogeneous in spite of the many different countries of origin for the members of the Arab community in Germany. This could to some extent be attributed to the influence of the country of residence, Germany, which is governed by the principles of democracy and political and cultural pluralism, , which in turn may have reflected positively on the political culture of the members of the Arab community.

\subsection{Recommendations}

In light of the findings of the study, a set of recommendations is offered through which we are trying to show the political cultural components of the Arab community in Germany:

First: To do further studies on the political culture of the Arab community in Germany, with its various dimensions, to enrich the subject and the results of scientific studies. It might be useful to employ those methods outlined which belong in the qualitative tradition of research of political culture in order to be able to explain the findings better.

Second: There is need for improved communication between the formal and informal German institutions with members of the Arab community, which could contribute to strengthen the relationship between the members of the Arab community and German society, which increases their integration into the host society.

Third: There is need to encourage members of the Arab community in Germany to get involved and participate more in political life in Germany either to participate in the general elections or affiliation to German political parties.

\section{Acknowledgments}

The researcher is grateful to, DFG for their financial support, Jena University for their assistance to do this work, particularly Prof. Dr. Torsten Oppelland and member staff of the Institute of Political Science.

\section{References}

Al-Dajah Abdullah, H., Mubark Mamoon, M., \& AL-Oweimer Abdullhadi, W. (2012). Views of the Arab Community in Relation to Cultural Identity and Social Integration in Germany. Canadian Social Science, 8(1), 191-199.

Al-Dajah, H. A. A., Oppelland, T., Mubark, M. M, AL-Oweimer, W., \& Malkawi, N. (2013). Political Integration Levels of Arab Community in Germany. International Journal of Multidisciplinary Thought, 3(2), 185-192.

Almond, G. (1989). The Intellectual History of the Civic Culture Concept. In G. Almond, \& S. Verba (Eds.), The Civic Culture Revisited (pp. 1-36). Newbury Park: Sage Publications.

Almond, G., \& Verba, S. (1963). The Civic Culture. Political Views and Democracy in Five Nations. Princeton N.J.: Princeton University Press.

Bergen, D. L. (2000). Controversies about the Holocaust: Goldhagen, Arendt, and the Historians' Conflict. In H. Lehmann (Ed.), Historikerkontroversen (pp. 141-174). Göttingen: Wallstein.

Conradt, D. P. (1989). Changing German Political Culture. In G. Almond, \& S. Verba (Eds.), The Civic Culture Revisited (2nd ed., pp. 212-272). Newbury Park: Sage Publications.

Dörner, A. (1996). Politischer Mythos und symbolische Politik. Der Hermannsmythos: Zur Entstehung des Nationalbewußtseins der Deutschen, Reinbek bei Hamburg: Rowohlt.

Edinger, M., \& Hallermann, A. (2004). Politische Kultur in Ostdeutschland. Die Unterstützung des politischen Systems am Beispiel Thüringens. Frankfurt/M.: Peter Lang.

Eurobarometer: http://ec.europa.eu/public_opinion/index_en.htm.

Gharaibeh, M. (1994). Khalil the Pattern of Political Culture among the students of the University of Yarmouk field study. Yarmouk Journal of Research, series of Humanities and Social Sciences, 10(1), 151-177.

Gharaibeh, M. K., \& Nofal, A. S. (2004, April). the political culture of Jordanian students in stageof Secondary school, a comparative study of students in government schools and foreign schools. Al-Nahda Journal, (19), 5-33.

Hashim Tawel, S. Q. (2009). after the national education course in changing the pattern of political culture among the students of the University of Al-Hussein Bin Talal. Journal of the Association of Arab Universities for Literature, VI(1), 67-84.

Inglehart, R., \& Welzel, C. (2010). Modernization, Cultural Change, and Democracy. The Human Development 
sequence (9th ed.). Cambridge: Cambridge University Press.

Kaase, Max, Sinn oder Unsinn des Konzepts "Politische Kultur" für die Vergleichende Politikforschung, oder auch: Der Versuch, einen Pudding an die Wand zu nageln, in: Max Kaase/Klingemann, Hans-Dieter (eds.), Wahlen und politisches System. Analysen aus Anlaß der Bundestagswahl 1980, Opladen: Westdeutscher Verlag 1983, 144-171.

Kailitz, S. (2001). Die politische Deutungskultur im Spiegel des "Historikerstreits". What's right? What's left. Wiesbaden: Westdeutscher Verlag. http://dx.doi.org/10.1007/978-3-322-83371-6

Matteo Gianni et al. (2005) Junge Muslime in der Schweiz. Identitätsprofile, Erwartungen und Einstellungen. Eine Studie der Forschungsgruppe «Islam in der Schweiz» (GRIS), Geneve.

Omri, B. K. (1997). The impact of social variables - economic on political culture of public university professors, Amman Information and Communication Center.

Rohe, K. (1990). Politische Kultur und ihre Analyse. Probleme und Perspektiven der politischen Kulturforschung. Historische Zeitschrift, 250, 321-346.

Rohe, K. (1994). Politik. Begriffe und Wirklichkeiten. Eine Einführung in das politische Denken, Stuttgart et. al.: Kohlhammer (2nd printing).

Street, J. (1994). Review Article: Political Culture - from Civic Culture to Mass Culture. British Journal of Political Science, 24, 95-113. http://dx.doi.org/10.1017/S0007123400006803

Sultan Nasser Qoran. (2005). the political culture in rural Jordan: Mmman: Ministry of Culture.

Westle, B. (2009). Chapter 2: Rezeptionsgeschichte des Konzepts der Politischen Kultur. In B. Westle, \& O. W. Gabriel (Eds.), Politische Kultur. Eine Einführung (pp. 24-39). Baden-Baden: Nomos,

Wilamowitz-Moellendorff, U. von. (2001). Türken in Deutschland - Einstellungen zu Staat und Gesellschaft. Sankt Augustin: Konrad-Adenauer-Stiftung.

Zmerli, S., \& Hooghe, M. (Eds.). (2011). Political Trust. Why Contexts Matter. Colchester: ECPR Press.

\section{Notes}

Note 1. Federal Statistical Office Germany, reference number: 288957 / 378670 dated: 20-07-2012.

Note 2. Yazīdī, also spelled Yezīdī, Azīì̄, Zedī, or Izdī, religious sect, found primarily in the districts of Mosul, Iraq; Diyarbakır, Turkey; Aleppo, Syria; Armenia and the Caucasus region; and parts of Iran. The Yazīdi religion is a syncretic combination of Zoroastrian, Manichaean, Jewish, Nestorian Christian, and Islamic elements. The Yazīi themselves are thought to be descended from supporters of the Umayyad caliph Yazīd I. They believe that they were created quite separately from the rest of humankind, being descended from Adam but not from Eve, and they have kept themselves strictly segregated from the people among whom they live. Although scattered and probably numbering only between 200,000 and 1,000,000, they have a well-organized society, with a chief sheikh as the supreme religious head and an emir, or prince, as the secular head.( http://www.britannica.com/EBchecked/topic/652325/Yazidi)

\section{Copyrights}

Copyright for this article is retained by the author(s), with first publication rights granted to the journal.

This is an open-access article distributed under the terms and conditions of the Creative Commons Attribution license (http://creativecommons.org/licenses/by/3.0/). 